\title{
Remediating Chlorpyrifos-Contaminated Soil Using Immobilized Microorganism Technology
}

\author{
Xin Wang ${ }^{1}$, Shi Yu Sun ${ }^{1}$, Jia Liang Lu², Jia Bao ${ }^{1 *}$ \\ ${ }^{1}$ School of Science, Shenyang University of Technology, Shenyang, China \\ ${ }^{2}$ Pinghu Environmental Protection Bureau of Zhejiang Province, Pinghu, China
}

Received: 3 December 2017

Accepted: 20 January 2018

\begin{abstract}
Chlorpyrifos, one of the common broad-spectrum insecticides, can damage the human nerve system - even to the point of death under long-term exposure. In addition, chlorpyrifos is hard to be naturally degraded because of its strong combination with soil particles and long half-life. So repairing the polluted soil is urgently needed. In this study, the embedding and crosslinking immobilization techniques were used to determine the degradation of chlorpyrifos in soil. After 16SrDNA analysis, the results showed that LLBD2 is Bacillus cereus and LLBD4 is bacillus sp., and bacteria immobilized on the degradation of chlorpyrifos were significantly better than the free bacteria. The degradation rate reached $83.28 \%$ after LLBD2 being immobilized within $72 \mathrm{~h}$. Furthermore, the environmental factors influenced with LLBD2 showed that immobilized bacteria were more adapted to the changed environment than the free one. Although the initial concentration, $\mathrm{pH}$, and temperature were significantly changed, the degradation rate of chlorpyrifos by immobilized bacteria was stable, suggesting that environmental factors had little influence on the immobilized bacteria.
\end{abstract}

Keywords: immobilization, Bacillus cereus, Bacillus sp, embedding-cross-linking, degradation rate

\section{Introduction}

O,O-Diethyl-O-(3,5,6-trichloro-2-pyridyl) phosphorothioate is one of the most extensively used organophosphate pesticides throughout the world. Chlorpyrifos is stable at room temperature and shows a white granular crystal [1], it is insoluble in water and soluble in most organic solvents, and is easily decomposed in alkaline medium. 3,5,6-trichloro-2pyridinol (TCP) is a metabolite of chlorpyrifos and

*e-mail: baojia@sut.edu.cn chlorpyrifos-methyl, both of which are organophosphorus pesticides [2]. Chlorpyrifos was prepared by the reaction of 3,5,6-trichloro-2-pyridinol with diethyl chlorothiophosphate. Chlorpyrifos is used around the world to control pest insects in agricultural, residential, and commercial settings [3]. The crops with the most use are cotton, corn, almond, and fruit trees, including oranges, bananas, and apples [4]. An annual growth of $10 \%$ in the global demand for chlorpyrifos is expected, with more than 200,000 ton by the end of 2015 .

As an effective insecticide, chlorpyrifos is widely accepted, but its potential dangers are not negligible for human health and the environment. It is reported 
Table 1. Immobilized microorganism and remediation of contaminated soil.

\begin{tabular}{|c|c|c|c|c|}
\hline Subject & Action object & Carrier & Research results & References \\
\hline Candida tropicalis & Benzopyrene & $\begin{array}{l}\text { Polyvinyl alcohol } \\
\text { Sodium alginate } \\
\text { Activated carbon }\end{array}$ & $\begin{array}{l}\text { The rate of degradation of benzo (a) } \\
\text { pyrene was } 40.65 \% \text { by physically } \\
\text { embedded IM } 219-220 \text {-phy }\end{array}$ & [15] \\
\hline Fungal oxalate plum ZHJ6 & Methamidophos & PET non-woven fabrics & $\begin{array}{c}\text { Fourth-day methamidophos } \\
\text { degradation rate is more than } 90 \% ; \\
\text { sixth-day degradation rate was } 100 \%\end{array}$ & [16] \\
\hline Reverse micelles laccase & DDTs & Diatomaceous earth & $\begin{array}{l}\text { The degradation rate of DDTs was } \\
20 \% \text { higher than that of free laccase }\end{array}$ & [17] \\
\hline Serratia & $\begin{array}{l}\text { Bensulfuron } \\
\text { methyl }\end{array}$ & Porous charcoal & $\begin{array}{l}\text { After } 28 \mathrm{~d} \text {, paddy soil of benzyl its } \\
\text { cycling degradation rate was } 62 \%\end{array}$ & [18] \\
\hline $\begin{array}{l}\text { Sporolactobacillus, } \\
\text { Micrococcus, } \\
\text { Pseudomonas }\end{array}$ & polyacrylamide & $\begin{array}{l}\text { Polyvinyl Alcohol } \\
+ \text { sodium alginate } \\
+ \text { Additives } \\
\end{array}$ & $\begin{array}{c}\text { The removal rate of polyacrylamide } \\
\text { by immobilized particles was up to } \\
79.5 \%\end{array}$ & [19] \\
\hline Klebsiella sp. Strain & $\begin{array}{c}\text { Aromatic } \\
\text { hydrocarbon }\end{array}$ & PUF & $\begin{array}{l}\text { It has better degradation rate and can } \\
\text { be reused } 36 \text { times }\end{array}$ & [20] \\
\hline Fungal Laccase & Fenarimol & Chitosan & $\begin{array}{l}\text { Immobilized enzyme in the } \mathrm{pH} \text { value } \\
\text { of } 4.0 \text {, the degradation rate of } 30 \% \text {, } \\
\text { enzyme activity recovery rate from } \\
58.5 \% \text { to } 58.5 \%\end{array}$ & [21] \\
\hline esterase B1 & $\begin{array}{l}\text { Organophosphorus } \\
\text { pesticides }\end{array}$ & Sodium alginate & $\begin{array}{c}\text { Degradation rate of methyl parathion } \\
\text { in } 1,000 \mathrm{mg} / \mathrm{L} \text { by immobilized } \\
\text { enzyme in } 3 \mathrm{~h}>65 \%\end{array}$ & {$[22]$} \\
\hline
\end{tabular}

that chlorpyrifos is suspected to be an environmental endocrine-disrupting substance, with low-dose residues having significant biological toxicity that can be hazardous to the endocrine, respiratory, nervous, or immune systems [5-6]. Chlorpyrifos is used for agricultural production, except as an insecticide, most of them eventually entering the soil environment, degrading slowly in the soil, and the residual period is long, with potential hazards to the soil ecosystem [7-8]. Residual chlorpyrifos in soil also leaches, which can pollute groundwater and surface water through percolation and runoff. With the increase in dosage, chlorpyrifos was detected in soil, water, and other environments in many countries and regions, and the residue and degradation in the environment should be highly valued.

Considering these negative effects, it is necessary to look for effective remedies to protect environmental sustainability. traditional methods are photodegradation, physical degradation, chemical methods [9], heat treatment [10], microbiological degradation [11], etc. Zhang [12] used ultrasonic air purification to clean organophosphorus pesticide chlorpyrifos, and the experiment showed that when bubble intensity was $25 \mathrm{~m}^{3} / \mathrm{h}$, ultrasonic power was $1000 \mathrm{~W}$, clean for $15 \mathrm{~min}$ to get the best effect. Xu [13] studied the combined microbial biodegradation of chlorpyrifos, firstly, 3,5,6-trichloro-2-pyridyl (TPC) degraded by Serratia sp, then TCP completely mineralized by Trichosporon sp. Bioremediation is a widely used method of repair that can improve stability and repair results. Chemical or physical methods are used to disperse biocatalysts (cells or enzymes) into a limited field [14]. Now immobilized microorganism technology, especially using different carriers to immobilize microorganisms, are widely used in soil degradation. The most common methods are embedding and adsorption, but the number of immobilized microorganisms is affected greatly by the carrier and the effect is unstable. Table 1 shows immobilized microorganisms and remediation of contaminated soil. It not only improves the concentration of microbial cells, but also maintains high activity and microbial technology $[10,23]$. This technology can greatly enhance the ability to adapt to the environment and increase the degradation of organic microorganisms [24], so as to improve the remediation of pesticide-contaminated soil. An immobilized carrier can enrich the strain [25] and extracellular enzymes, and can also improve contact efficiency between microorganisms and contaminated soil. So immobilized microorganism technology not only enhances the stability of microorganisms, but it also enhances environmental impact resistant ability and increases the number of inoculated microbes and activity, and the reaction initiation rate of degraded pesticides was also accelerated [26].

The objectives of this study were: 1) obtain the dominant degrading bacteria of chlorpyrifos, 2) compare the effect of chlorpyrifos degradation by immobilized bacteria or free bacteria, and 3) compare the adaptability of immobilized bacteria and free bacteria to environmental change. 


\section{Experimental}

\section{Materials and Methods}

The specific dominant degrading bacteria of chlorpyrifos were domesticated and trained in the microbiological laboratory of Shenyang University of Technology. The soil samples were collected from the original factory area of Shenyang Northeast Pharmaceutical Factory, which belongs to the pharmaceutical-contaminated soil. The chlorpyrifos was bought from Shandong Rongbang Pesticide Chemical Co., Ltd (China). Sodium alginate, Polyvinyl alcohol, $\mathrm{Na}_{2} \mathrm{SO}_{4}$, and $\mathrm{FeCl}_{3}$ were purchased from Tianjin Bo Di Chemical Co., Ltd (China). RTaqDNA polymerase, dNTPs, and T4DNA ligase were purchased from TaKaPa Engineering Company. Dichloromethane was purchased from Tianjin Fuyu Fine Chemical Co., Ltd. (China). Methanol was purchased from Thermo Fisher Scientific.

PCR Amplification instrument (Bio-Rad, American) was used to amplify specific DNA fragments. Highperformance liquid chromatography (HPLC, Agilent 1260 , Singapore) was used to determine the degradation rate of chlorpyrifos.

\section{Methods}

\section{Enrichment of Degrading Bacteria}

Two kinds of soil samples collected from wet soil and dry soil were added into distilled water and shocked for $2 \mathrm{~h}$, then supernatant fluid of $150 \mathrm{~mL}$ was added to the conical flask. They were labeled as dry and wet samples, and chlorpyrifos was added (at that time the concentration was $16 \mathrm{mg} / \mathrm{L})$. The 2 conical bottles were placed in a constant temperature, shaken, and cultured for $48 \mathrm{~h}$. Enrichment culture of degrading bacteria needed 7 cycles, and the concentration of pesticide was increased appropriately during each transfer process (the specific values of pesticide concentrations are shown in Table 2).

Table 2. Water sample enrichment in each cycle of chlorpyrifos concentration.

\begin{tabular}{|c|c|}
\hline Enrichment cycle (d) & $\begin{array}{c}\text { Chlorpyrifos concentration } \\
(\mathrm{mg} / \mathrm{L})\end{array}$ \\
\hline 7 & 16.0 \\
\hline 14 & 32.0 \\
\hline 21 & 34.0 \\
\hline 28 & 64.0 \\
\hline 35 & 76.8 \\
\hline 42 & 96.0 \\
\hline 49 & 128.0 \\
\hline
\end{tabular}

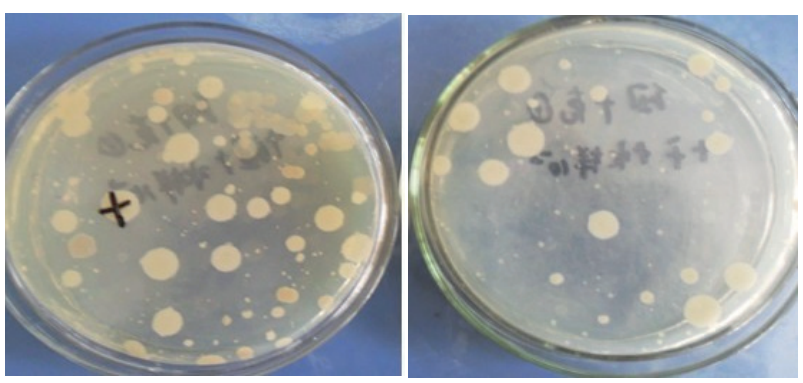

Fig. 1. Bacterial colonies on the culture medium.

\section{Isolating Bacteria}

Solid culture medium was placed in a $500 \mathrm{~mL}$ erlenmeyer flask and chlorpyrifos was added at $16 \mathrm{mg} / \mathrm{L}$. After sterilization, all instruments and culture medium were quickly taken into a sterile room to 10 prepared tablets and they were marked. When the medium was well solidified, five cycles of water were inoculated with inoculating ring, and all of the tablets had making-on cassion and were cultured for $48 \mathrm{~h}$, with a single colony growing well as shown in Fig. 1.

\section{Purifying Bacteria}

After domesticating the strain (in which the healthy colonies were selected and transferred to the corresponding slant medium for purification), 10 strains of chlorpyrifos-degrading bacteria were obtained and marked as LLBD1-10.

\section{Primary Screening of Degrading Bacteria}

$0.100 \mathrm{~g}$ of chlorpyrifos was accurately weighed and put into a $100 \mathrm{~mL}$ volumetric flask, then sized down with methanol, $1 \mathrm{~mL}, 2 \mathrm{~mL}, 2.5 \mathrm{~mL}, 3 \mathrm{~mL}$, and $5 \mathrm{~mL}$ of solution taken into five $25 \mathrm{~mL}$ volumetric flasks, respectively, and constanted volume with methanol. The concentration was diluted to $40,80,100,120$, and $200 \mathrm{mg} / \mathrm{L}$, then measured by high-performance liquid chromatography (HPLC), and repeated three times. Chlorpyrifos standard curve was $\mathrm{Y}=1.6735$ $\mathrm{X}-12.076, \mathrm{R}^{2}=0.9993$. In a sterile room, 11 doses of chlorpyrifos were prepared in $100 \mathrm{mg} / \mathrm{L}$, and labled as LLBD1-LLB10, and the other was blank control. Then they were placed in a constant temperature shaker and after cultivation for $48 \mathrm{~h}$ and $72 \mathrm{~h}$ the samples were performed.

\section{Rescreening Degradation Bacteria}

The preliminary screening out of 5 chlorpyrifos dominant-degrading microorganisms were screened again. In a sterile room, 6 doses of chlorpyrifos were prepared in $100 \mathrm{mg} / \mathrm{L}$ and marked. Then, the same strains were added to erlenmeyer flask, and one of them was a control. 
Water Sample Analysis

200, 120, 100, 80, and $40 \mathrm{mg} / \mathrm{L}$ chlorpyrifos were prepared as test water samples, and these samples were extracted by dichloromethane, then the extracted samples were determined by high-performance liquid chromatography (HPLC), and the recovery rate of chlorpyrifos in water samples was calculated by the result of determination. The results suggest that the average recovery rate of chlorpyrifos in water samples was $89.45 \%$, which indicated that the method was feasible.

\section{Small Extraction of Bacterial Genomic DNA}

First, a single colony of bacteria was picked in a sterile room and accessed into 5-10 mL LB liquid to cultivate for a night. The bacterial fluid of logarithmic growth phase was split-charged into $1.5 \mathrm{~mL}$ centrifuge tubes centrifuged for $2 \mathrm{~min}$ at $12,000 \mathrm{r} / \mathrm{min}$, the supernatant fluid was discarded, and bacteria were collected, then washed clean with $1 \mathrm{~mL}$ STE. $567 \mu \mathrm{L}$ of TE buffer was put in a liquid gun and blown repeatedly, and then $30 \mu \mathrm{L}$ $10 \%$ SDS (sodium dodecylsulfate) with $3 \mu \mathrm{L}$ proteinase $\mathrm{K}$ were added, the mixture was evenly inverted and placed in a $37^{\circ} \mathrm{C}$ water bath for $1 \mathrm{~h}$. Then $100 \mu \mathrm{L} 5 \mathrm{~mol} / \mathrm{L}$ $\mathrm{NaCl}$ solution was put in a container and mixed evenly. $80 \mu \mathrm{L}$ of $\mathrm{CTAB} / \mathrm{NaCl}$ solution was mixed well and took to a $65^{\circ} \mathrm{C}$ water bath to heat for $20 \mathrm{~min}$. Then equal volume (780) chloroform/isoamyl alcohol (24:1) were added and centrifuged for $15 \mathrm{~min}$ at $12,000 \mathrm{r} / \mathrm{min}$. Equal volumes of phenol/chloroform/isoamyl alcohol (25:24:1) were put in it and centrifuged for $5 \mathrm{~min}$ at $12000 \mathrm{r} / \mathrm{min}$, and the supernatant was discarded. Next, equal volume (780) chloroform/isoamyl alcohol (24:1) was added and it was centrifuged for $15 \mathrm{~min}$ at $12000 \mathrm{r} / \mathrm{min}$. Then, equal volume of $-20^{\circ} \mathrm{C}$ isopropyl alcohol was added and mixed until DNA flocculent precipitation was seen, and then it was allowed to stand for 3-5 min. Finally, supernatant was removed, 70\% ethanol was added and shaken gently, and then the sample was washed with $100 \%$ alcohol and centrifuged for $5 \mathrm{~min}$ at $12000 \mathrm{r} / \mathrm{min}$, supernatant was discarded and dried sterilely, and a suitable amount of TE buffer was added to dissolve completely and it was preserved at $-20^{\circ} \mathrm{C}$.

\section{Bacteria 16SrDNA Amplified PCR}

The forward primer for PCR amplification is $16 \mathrm{~S}-8$ F1:5'-AGA GTT TGA TYM TGG CTC AG-3'(Y=C/T, $\mathrm{M}=\mathrm{A} / \mathrm{C}$ ) and reverse primer is ITS-23-R:'-CCG GGT TTC CCC ATT CGG-3' [27].

PCR reaction procedures are as follows: the sample was predegenerated for $4 \mathrm{~min}$ at $94^{\circ} \mathrm{C}$, degenerated for $1 \mathrm{~min}$, annealed for $50 \mathrm{~s}$ at $55^{\circ} \mathrm{C}$, and extended for $2 \mathrm{~min}$ at $72^{\circ} \mathrm{C}$. The steps above were repeated 34 times and extended for $10 \mathrm{~min}$ at $72^{\circ} \mathrm{C}$. The resulting DNA sequences were entered into GenBank for Blast retrieval, selected and download the corresponding sequence, and the nucleotide sequences obtained by DNASTAR,
Table 3. 16SrDNA of amplification reaction system in PCR.

\begin{tabular}{|c|c|}
\hline Project & volume $(\mu \mathrm{L})$ \\
\hline $10 *$ PCR Buffer $\left(\mathrm{Mg}^{2+}\right)$ & 2.5 \\
\hline dNTPMixture $(2.5 \mathrm{mmol} / \mathrm{L})$ & 2 \\
\hline Primer F $(5 \mu \mathrm{mol} / \mathrm{L})$ & 2 \\
\hline Primer R $(5 \mu \mathrm{mol} / \mathrm{L})$ & 2 \\
\hline Template DNA & 1 \\
\hline rTaq polymerase $(5 \mathrm{U} / \mu \mathrm{L})$ & 0.25 \\
\hline Aseptic dd $\mathrm{H}_{2} \mathrm{O}$ & 15.25 \\
\hline Bulk volume & 25 \\
\hline
\end{tabular}

DNAMAN 4.0, and MEGA 3.1 software were compared and analyzed with the nucleotide sequence of the corresponding group included in the GenBank.

\section{Bacteria Immobilization}

$10 \mathrm{~g}$ polyvinyl alcohol, $0.5 \mathrm{~g}$ alginate, and $5 \mathrm{~g}$ activated carbon were accurately taken and put in a $100 \mathrm{~mL}$ beaker containing $60 \mathrm{~mL}$ distilled water. The next day it was sterilized for $30 \mathrm{~min}$ at $110^{\circ} \mathrm{C}$ and cooled to about $40^{\circ} \mathrm{C}$. Then, $20 \mathrm{~mL}$ bacterial fluid was predetermined volume added to $100 \mathrm{~mL}$ with aquae sterilisata, and fed into a granulator to be crosslinked by crosslinking agent for $24 \mathrm{~h}$ after being mixed evenly. The cross-linking agent was saturated boric acid solution $(300 \mathrm{~mL})$, and a small amount of calcium chloride and ferric chloride was made into a spherical carrier with a diameter of $2.5 \mathrm{~mm}$. To ensure the strength of the immobilized ball, pellets were placed in a sodium sulfate solution of a mass ratio of $10 \%$ to stabilize $24 \mathrm{~h}$. Then it washed and soaked by water after immobilization, and proliferated in the multiplication medium and labled as $\mathrm{H} 1$.

\section{Preparing Chlorpyrifos-Contaminated Soil}

First, a soil sample was collected and filtered through 20 mesh at room temperature, and chlorpyrifos was accurately weighed and dissolved into $500 \mathrm{~mL}$ volumetric flask containing methanol. For each test, $15 \mathrm{~mL}$ chlorpyrifos solution with $30 \mathrm{~g}$ soil was placed in a $250 \mathrm{~mL}$ conical flask, and at that moment the mass concentration of chlorpyrifos in soil was $100 \mathrm{mg} / \mathrm{L}$. Next, $90 \mathrm{~mL}$ bacterial culture solution was added to the sample and made into slurry (soil water ratio was 3:1) after the soil has dried naturally, and then it was put into an autoclave sterilizer. Each sample was made of 3 parallel samples.

\section{Determining Degradation Rate}

$1.00 \mathrm{~mL}$ slurry-containing pesticide with $10.00 \mathrm{~mL}$ methylene chloride was put into a glass centrifuge tube. Next, it was oscillated for $10 \mathrm{~min}$ at $300 \mathrm{r} / \mathrm{min}$ and placed 
in an intermittent ultrasonic bath for $2 \mathrm{~h}$. Then it was centrifuged for $5 \mathrm{~min}$ at $5000 \mathrm{r} / \mathrm{min}$, and constanted volume with methanol to $25 \mathrm{~mL}$ in a volumetric flask after the supernatant was left and dried. Finally, $1 \mathrm{~mL}$ sample was absorbed by a syringe with a $0.45 \mu \mathrm{m}$ organic filter and moved into the sample bottle for high-performance liquid chromatography (HPLC).

\section{The Conditions of HPLC}

The mobile phase was prepared with methyl alcohol and distilled water (proportion 78:22). UV wavelength was set to $280 \mathrm{~nm}$ at room temperature. The sample size was $10 \mathrm{uL}$ at a rate of $1.2 \mathrm{~mL} / \mathrm{min}$ and the retention time was $11.3 \mathrm{~min}$.

The removal ratio of chlorpyrifos in soils was calculated as follows:

$$
\text { Removal ratio }(\%)=100 \times\left(\mathrm{C}_{0}-\mathrm{Cx}\right) / \mathrm{C}_{0}
$$

...where $\mathrm{C}_{0}$ and $\mathrm{Cx}$ are the peak area of chlorpyrifos before and after degradation, respectively. An experiment was also performed using free bacteria of an equal weight under the same conditions.

\section{Data Processing Tools}

Microsoft Excel was applied to process all the experimental data. SPSS 10.0 was applied for statistical analysis, Duncan's multiple comparison correction, on the different experimental conditions, which were used to evaluate the degradation efficiency of chlorpyrifos, and $p<0.05$ was considered a significant difference.

\section{Results and Discussion}

\section{Effect of Degrading Strain on Degradation of Chlorpyrifos}

As shown in Fig. 2, after primary screening experiments the results showed that LLBD2, LLBD3, LLBD4, LLBD6, and LLBD7 had better effects on the degradation of chlorpyrifos. After $48 \mathrm{~h}$, their degradation rates respectively reached $73.64 \%, 51.12 \%, 64.56 \%$, $58.31 \%, 47.85 \%$, and at $72 \mathrm{~h}$ the degradation rates were $94.74 \%, 76.53 \%, 93.29 \%, 77.81 \%$, and $80.34 \%$. Compared with the other 5 strains, degradation efficiency of chlorpyrifos was improved and has obvious advantages. In addition, some strains reached the desired degradation effect after $72 \mathrm{~h}$.

As shown in Fig. 3, the results showed that the degradation efficiency of chlorpyrifos was the same as that of the primary screening, among them the optimal degradation efficiencies of the 2 strains were LLBD2 and LLBD4. The degradation rate was $70.6 \%$ and $61.5 \%$ after $48 \mathrm{~h}$, respectively, and after $72 \mathrm{~h}$ the degradation rates were $92.3 \%$ and $91.4 \%$. The data was the average

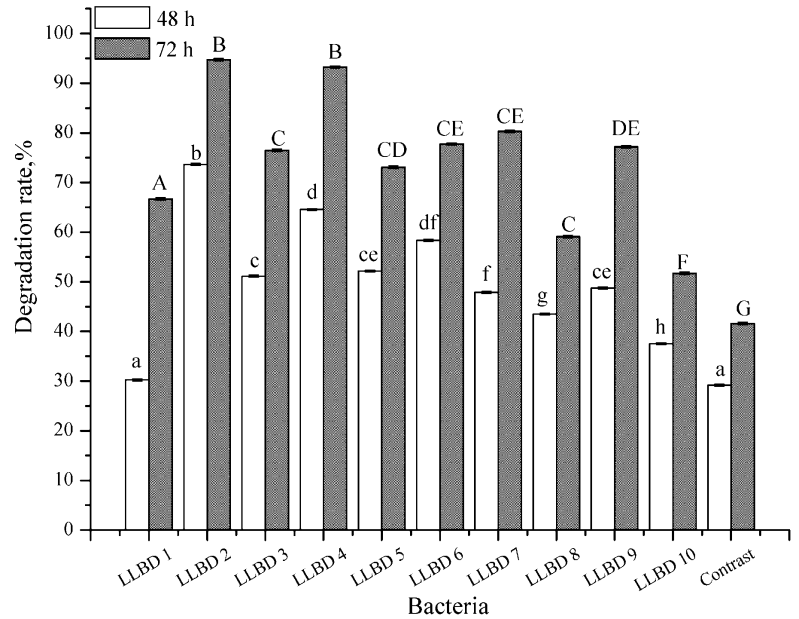

Fig. 2. Screening chlorpyrifos-degrading bacteria.

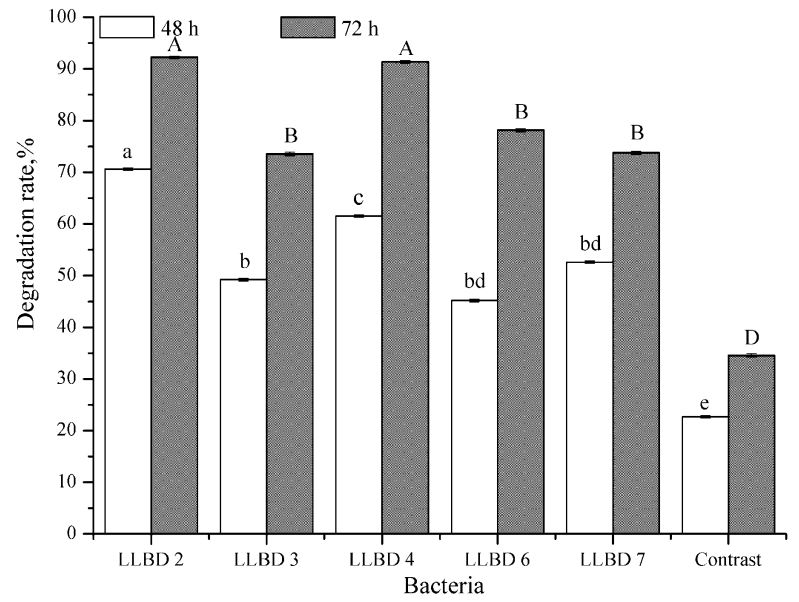

Fig. 3. Rescreening chlorpyrifos-degrading bacteria.

\pm standard error $(\mathrm{n}=3)$, different letters indicating a significant difference in the rate of degradation strains $(p<0.05)$, while the same letter indicates it had no significant difference.

\section{SrDNA Identification of Bacteria}

In the degradation experiment of chlorpyrifos, LLBD2 and LLBD4 were the dominant bacteria, and their sequence results of 16SrDNA were compared with GenBank data by Blast program. The results showed that the homology between LLBD2 and Bacillus cereus strain BDU8 was $99 \%$, while the homology between LLBD4 and Bacillus sp. A57 was $99 \%$. Preliminary identification results showed that LLBD2 was Bacillus cereus, LLBD4 was Bacillus sp. Bacillus cereus and Bacillus sp were observed under the microscope at 1000 times, as shown in Fig. 4 and Fig. 5. 


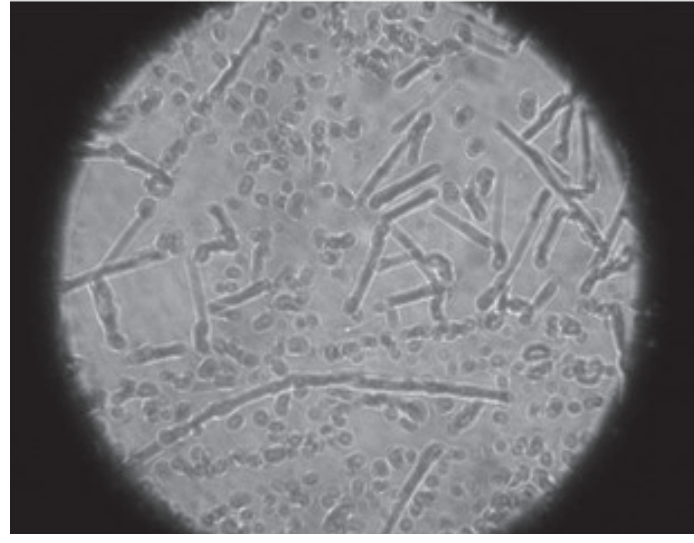

Fig. 4 Microphoto for Bacillus cereus.

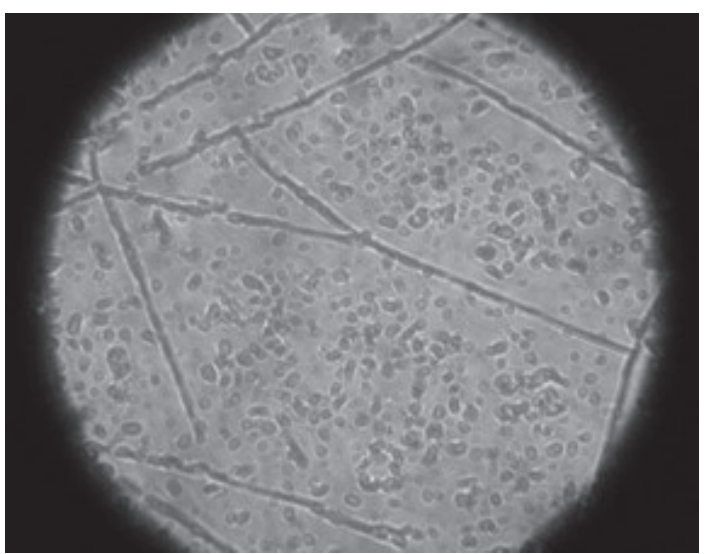

Fig. 5 Microphoto for Bacillus sp.

\section{Effect of Immobilized Nicroorganisms on Degradation of Chlorpyrifos}

As can be seen in Fig. 6, the degradation rate of chlorpyrifos obviously improved after the free bacteria were immobilized. Indeed, some studies have shown that the removal rate of chlorpyrifos using immobilized

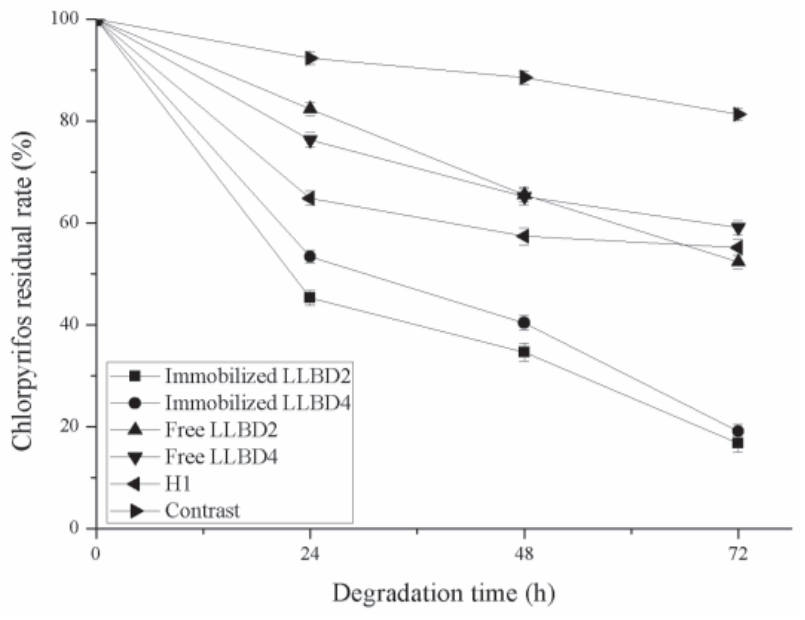

Fig. 6. Degradation of chlorpyrifos by immobilized strain in H1.

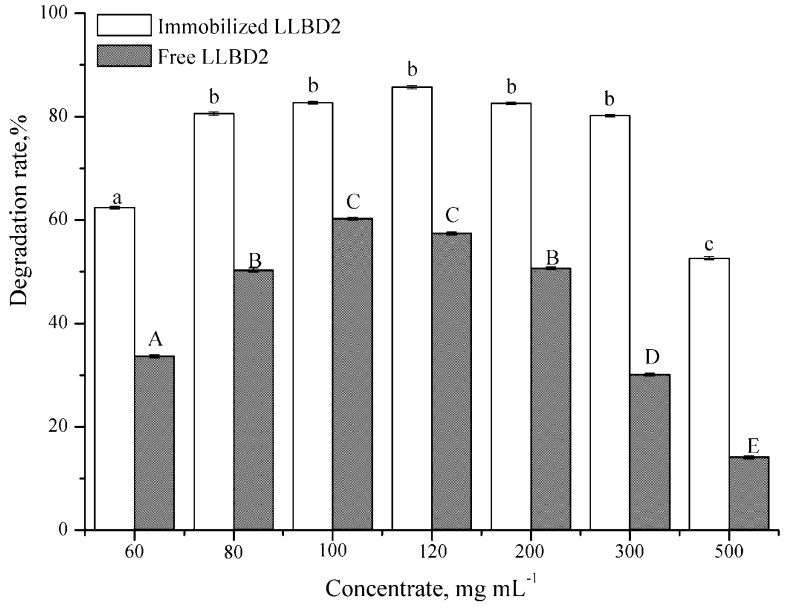

Fig. 7. The influence of initial concentration to immobilized bacteria degradation of chlorpyrifos.

bacteria was much higher than free bacteria [28], which should be attributed to the protection of immobilized pellets. After $24 \mathrm{~h}, 48 \mathrm{~h}$, and $72 \mathrm{~h}$, the residual rates of immobilized LLBD2 for chlorpyrifos were $45.29 \%$, $34.63 \%$, and $16.72 \%$, respectively, while residual rates of free LLBD2 were $82.33 \%, 65.51 \%$, and $52.33 \%$, respectively. In this experiment, whether it was immobilized or not, the degradation rate of chlorpyrifos by LLBD2 strain was slightly higher than LLBD4, so the LLBD2 strain was used for subsequent experiments.

\section{Removal Ratios of Initial Concentration on Chlorpyrifos}

For immobilized bacteria, when the initial concentration was $100 \mathrm{mg} / \mathrm{L}$, the highest removal ratio within 72 hours was $84.39 \%$, the initial concentration of chlorpyrifos increased from 60.0 to $100.0 \mathrm{mg} / \mathrm{L}$, and the removal ratio of chlorpyrifos increased from $60.10 \%$ to $84.39 \%$. As the initial concentration of chlorpyrifos continued to rise, the degradation rate of immobilized bacteria remained unchanged, the concentration reached $300 \mathrm{mg} / \mathrm{L}$, and the degradation rate began to decrease obviously. The optimal range of immobilized LLBD2 on the degradation of the initial concentration of chlorpyrifos was $80-300 \mathrm{mg} / \mathrm{L}$. The degradation ratio of chlorpyrifos under different initial chlorpyrifos concentrations is shown in Fig. 7.

LLBD2, without being immobilized, was greatly affected by the initial concentration of chlorpyrifos. For free bacteria, when the initial concentration of chlorpyrifos was increased from 100 to $500 \mathrm{mg} / \mathrm{L}$, degradation rate of chlorpyrifos could be reduced from $60.01 \%$ to $14.13 \%$ within $72 \mathrm{~h}$. This showed that the range of tolerance of immobilized bacteria to chlorpyrifos was much wider than that in the free state. A high concentration of chlorpyrifos inhibited the growth of the strain and caused the degradation rate to decrease. Previous studies [29] showed that the degradation rate 


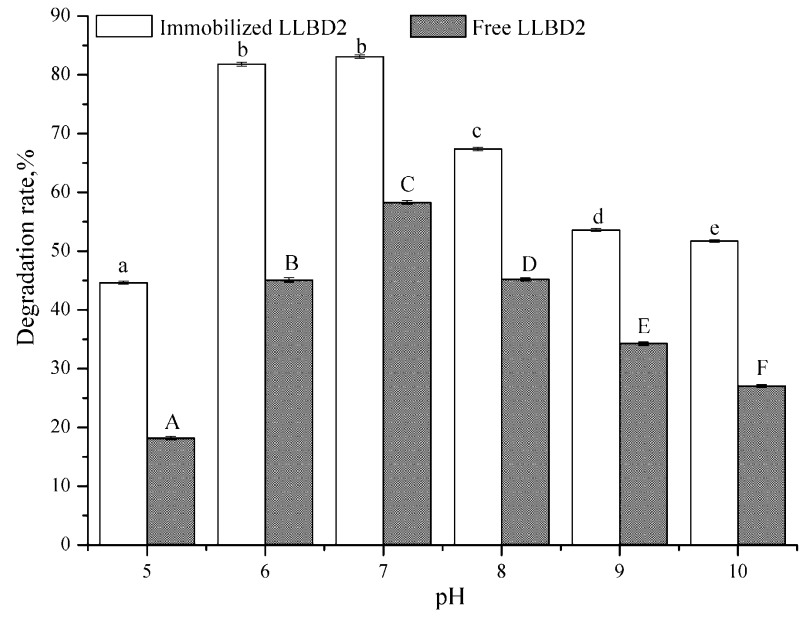

Fig. 8. The influence of $\mathrm{pH}$ on immobilized bacteria degradation of chlorpyrifos.

of chlorpyrifos by immobilized bacteria was higher than that of free bacteria, but the tolerance of immobilized bacteria to chlorpyrifos has a certain limitation.

\section{Removal Ratio of $\mathrm{pH}$ Value on Chlorpyrifos}

Under the state of different $\mathrm{pH}$ values, the removal ratio of chlorpyrifos was shown in Fig. 8. The immobilized bacteria had a wider $\mathrm{pH}$ range than the free one. When the $\mathrm{pH}$ value was 6.0-7.0, the degradation effect was better. The growth was best when the $\mathrm{pH}$ value was 7 and the degradation rate was $83.10 \%$. Alkaline conditions were easier to survive than acidic conditions, but too much acid or alkali would affect growth. And the $\mathrm{pH}$ of free LLBD2 strain has a narrow adaptation ability, when $\mathrm{pH}$ was lower than 7 or higher than 7 , the degradation rate fluctuated more widely. This showed that the immobilized carrier can protect the degrading bacteria and shield the harmful effects of the outside to a certain

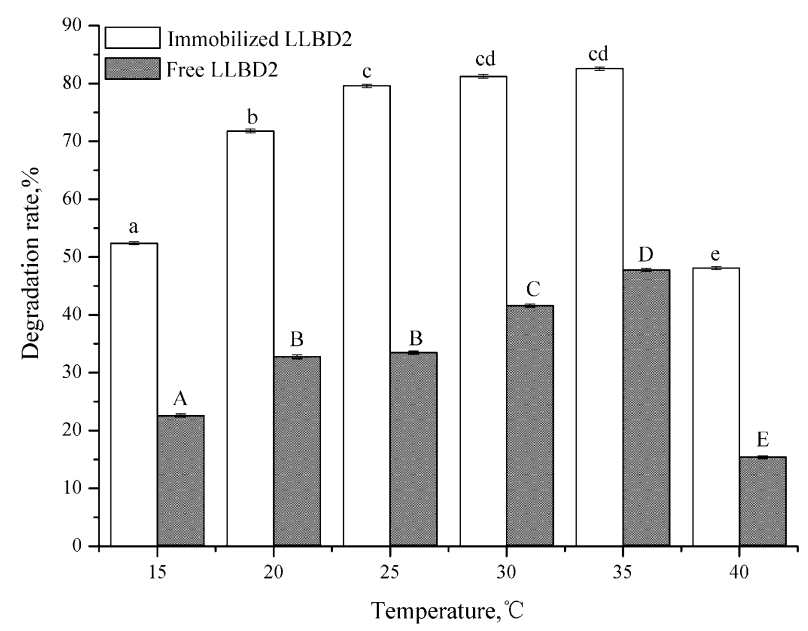

Fig. 9. Influence of temperature on immobilized bacteria degradation of chlorpyrifos. extent. Li Ying [30] showed that after degrading bacteria were immobilized, its tolerance to acid and alkali was significantly raised, but too acid or too alkaline also had an adverse effect on the biodegradation of chlorpyrifos $(p<0.05)$. Compared with free bacteria, the sensitivity of immobilized bacteria to $\mathrm{pH}$ was decreased.

\section{Removal Ratio of Temperature on Chlorpyrifos}

Temperature could affect the physiological metabolism and adsorption thermodynamics of bacteria and thus influence the degradation rate of chlorpyrifos in soils. For immobilized bacteria, the results in Fig. 9 showed that $35^{\circ} \mathrm{C}$ was the best temperature for the degradation of chlorpyrifos in soils, and the removal rate was $82.57 \%$. However, an extreme temperature also can cause a bad effect, and excess temperature could reduce the degradation rate. The experimental results were similar to Yen [31] et al., and $37^{\circ} \mathrm{C}$ was the best temperature for the degradation of chlorpyrifos in soils, and the removal ratio was $89.37 \%$. This might be mainly due to moderately increased soil temperature leading to the half-life of the cicada being shortened significantly, and also helping to improve enzyme activity.

\section{Conclusion}

In the experiment, the bacteria were immobilized by embedding and cross-linking, the results showing that the bacteria immobilized on chlorpyrifos degradation of pollutants was better than the free bacteria, and that halflife was also greatly shortened. After $72 \mathrm{~h}$, more than $83.28 \%$ of chlorpyrifos could be removed by immobilized LLBD2 which was higher than LLBD4. And compared with the free LLBD2, the immobilized LLBD2 has a wide range of environmental adaptation.

The effect of degradation could be better when the initial chlorpyrifos concentration was $80-300 \mathrm{mg} / \mathrm{L}$, $\mathrm{pH}$ value was $6.0-7.0$, and temperature was $25-35^{\circ} \mathrm{C}$. When the initial pollutant concentration, $\mathrm{pH}$, and temperature change greatly, immobilized bacteria were more adapted to environmental changes than free bacteria, and immobilized microorganisms were less affected by environmental factors and have strong adaptability, so their degradation rate was relatively stable.

The application of immobilized microorganism technology provides a new way for the remediating pesticide-contaminated soil. The direction of future research can be analyzed from three aspects:

1) The carrier is an important part of immobilization technology and is crucial to further developing an immobilized carrier model with good performance, improve the activity and concentration of the immobilized microorganism, and improve treatment effect and performance.

2) The actual pollutant is a complex system. It is difficult to meet the requirements for a single species 
generally, so whether use of mixed bacteria or single bacteria classification needs further research.

3) The scope of the current application of immobilization technology is still relatively small, combining genetic engineering bacteria and the immobilization technology can expand the types of pollutants for processing, so the idea that the immobilization technique can be widely used should be the focus of future research. In conclusion, immobilization technology is an important means for improving the ecological environment. Predictably, along with the continuous research and development of immobilization technology, the application of this technology in soil pollution control will be taken as a practical step.

\section{Acknowledgements}

This research is funded by the National Natural Science Foundation of China (No. 31670515) and the National Natural Science Foundation of China (No. 21507092).

\section{Conflict of Interest}

The authors declare no conflict of interest.

\section{References}

1. MARGARET S., BROOKE L., SARA C. Chlorpyrifos and neurodevelopmengtal effects: a literature review and expert elicitation on research and policy. Environ. Health. 11 (Suppl), 5, 2012.

2. BARATHIDASAN K., REETHA D., MILTON D.J., SRIRAM N., GOVINDAMMAL M. Biodegradation of chlorpyrifos by co-culture of Cellulomonas fimi and Phanerochaete chrysosporium. Afr. J. Microbiol. Res. 8 (9), 961, 2014.

3. RIYA P., JAGATPATI T. Biodegradation and bioremediation of pesticides in soil: its objectives, classification of pesticides, factors and recent developments. World J. Sci. Technol., 2, 36, 2012.

4. YADAV M., SRIVASTVA N., SINGH R.S., UPADHYAY S.N. Biodegradation of chlorpyrifos by Pseudomonas sp. in a continuous packed bed bioreactor. Bioresource Technol., 165, 265, 2014

5. SILAMBARASAN S., ABRAHAM J. Efficacy of Ganoderma sp. JAS4 in bioremediation of chlorpyrifos and its hydrolyzing metabolite TCP from agricultural soil. J. Basic Microbiol. 54, 44, 2014.

6. FLASKOS J. The developmental neurotoxicity of organophosphorus insecticides: A direct role for the oxon metabolites. Toxicol. Lett. 209, 86, 2012.

7. TIMOFEEVA O.A., LEVIN E.D. Lasting Behavioral Consequences of Organophosphate Pesticide Exposure During Development. In Hayes' Handbook of Pesticide Toxicology, $3^{\text {rd }}$ ed.; Krieger R., Academic Press, New York, 837, 2010.
8. JOHN E.M., SHAIKE J.M. Chlorpyrifos: pollution and remediation. Environ. Chem. Lett. 13 (3), 269, 2015.

9. IMFELD G, VUILLEUMIER S. Measuring the effects of pesticides on bacterial communities in soil: a critical review. Eur. J. Soil Biol. 49, 22, 2012.

10. KRITI K., FULEKAR M. Chlorpyrifos bioremediation in Pennisetum rhizosphere by a novel potential degrader Stenotrophomonas maltophilia MHF ENV20. World J. Microbiol. Biotechnol. 28 (4), 1715, 2012.

11. DHANYA M.S. Advances in microbial biodegradation of chlorpyrifos. J. Environ. Res. Develop. 9 (1), 232, 2014.

12. ZHANG Q., WANG B.C., CAO Z.Y.., YU Y.L. Plasmidmediated bioaugmentation for the degradation of chlorpyrifos in soil. J. Hazard. Mater. 221, 178, 2012.

13. GEBREMARIAM S.Y., BEUTEL M.W., YONGE D.R., FLURY M., HARSH J.B. Adsorption and desorption of chlorpyrifos to soils and sediments. In: Reviews of environmental contamination and toxicology. Whitacre D.M. (ed). Springer New York, New York, 123, 2012.

14. PÉREZ J, DOMINGUES I, MONTEIRO M, SOARES A.M.V.M., LOUREIRO S. Synergistic effects caused by atrazine and terbuthylazine on chlorpyrifos toxicity to early-life stages of the zebrafish Danio rerio. Environ. Sci. Pollut. Res. 20, 4671, 2013.

15. DIETZ A.C., SCHNOOR J.L. Advances in phytoremediation. Environ. Health Perspect. 109, 163, 2001.

16. ZHAO R.B., JIN C.H., LIU W.H. Effect of oxalic acid ZHJ6 immobilized on plum methamidophos degradation. Chin. Agri. Sci. Bull. 28 (26), 247, 2012.

17. ZHONG G., TANG J., XIE Z., MI W., CHEN Y., MÖLLER A., STURM R., ZHANG G., EBINGHAUS R. Selected current-use pesticides (CUPs) in coastal and offshore sediments of Bohai and Yellow seas. Environ. Sci. Pollut. Res. 22, 1653, 2015.

18. BARROS F.C.F., BARROS A.L., SILVA M.A., DO NASCIMENTO R.F. Use of microwave-assisted oxidation for removal of the pesticide chlorpyrifos from aqueous media. Int. J. Civil Environ. Eng. 13 (6), 16, 2013.

19. BRICENO G., FUENTES M.S., PALMA G., JORQUERA M.A., AMOROSO M.J., DIEZ M.C. Chlorpyrifos biodegradation and 3,5,6-trichloro-2-pyridinol production by actinobacteria isolated from soil. Int. Biodeter. Biodegr. 73, 1,2012

20. JAGANNATH C. KADAKOL, CHANDRAPPA M. KAMANAVALLI, YOGESH SHOUCHE Biodegradation of Carbofuran phenol by free and immobilized cells of Klebsiella pneumoniae ATCC13883T, World J. Microbiol. Biotechnol. 27 (1), 25, 2011.

21. GIESY J.P., SOLOMON K.R., GIDDINGS J.M., WILLIAMS W.M., SOLOMON K.R., GIESY J.P. Risks to aquatic organisms from use of chlorpyrifos in the United States. Rev. Environ. Contam. Toxicol. 231, 119, 2014.

22. CHISHTI Z., ARSHAD M. Growth linked biodegradation of chlorpyrifos by Agrobacterium and Enterobacter spp. Int. J. Agric. Biol. 15 (1), 19, 2012.

23. JOSE M., GUISAN. Methods in Molecular Biology. Immobilization of Enzymes and Cells. $3^{\text {rd }}$ ed.; Humana Press, Louisville, 1, 2013.

24. DEEPALI L., KORADE M., FULEKAR H. Rhizosphere remediation of chlorpyrifos in mycorrhizospheric soil using ryegrass. J. Hazard Mater. 172, 1344, 2009.

25. SAKAI S., LIU Y., YAMAGUCHI T., WATANABE R., KAWABE M., KAWAKAMI K. Enzyme immobilization 
an overview on techniques and support materials. Biotechnol. Lett. 32 (7), 1059, 2010.

26. LU P., LI Q., LIU H., FENG Z., YAN X., HONG Q., LI S. Biodegradation of chlorpyrifos and 3,5,6-trichloro-2pyridinol by Cupriavidus sp. DT-1. Bioresource Technol. 127, 337, 2013

27. BARMAN D.N., HAQUE M.A., ISLAM S.M.A., YUN H.D., KIM M.K. Cloning and expression of ophB gene encoding organophosphorus hydrolase from endophytic Pseudomonas sp. $\mathrm{BF}_{1-3}$ degrades organophosphorus pesticide chlorpyrifos. Ecotoxicol. Environ. Saf. 108, 135, 2014.

28. ZHAO C.Y., FU RONG Immobilization of laccase in reverse micelles and its usein remediation of DDTcontaminated soil. Ecol. Envir. 17 (2), 606, 2008.
29. CHAI L., WONG M., BRUUN HANSEN H.C. Degradation of chlorpyrifos in humid tropical soils. J. Environ. Manage. 125, 28, 2013.

30. REDDY A., MADHAVI V., REDDY K.G., MADHAVI G. Remediation of chlorpyrifos-contaminated soils by laboratory-synthesized zero-valent nano iron particles: effect of pH and aluminium salts. J. Chem. 2013, 7, 2012.

31. DUBEY K.K., FULEKAR M.H. Chlorpyrifos bioremediation in Pennisetum rhizosphere by a novel potential degrader Stenotrophomona smaltophilia MHF ENV20. J. Microbiol. Biotechnol. 28 (4), 1715, 2012. 
